University of Nebraska - Lincoln

DigitalCommons@University of Nebraska - Lincoln

2012

\title{
Evolution with depth from detrital to authigenic smectites in sediments from AND-2A drill core (McMurdo Sound, Antarctica)
}

\author{
Francesco lacoviello \\ Università degli Studi di Siena, iacoviello3@unisi.it \\ Giovanna Giorgetti \\ Università di Siena, giorgettig@unisi.it \\ Fernando Nieto \\ Universidad de Granada - CSIC, nieto@ugr.es \\ Isabella Turbanti Memmi \\ Università degli Studi di Siena, memmi@unisi.it
}

Follow this and additional works at: https://digitalcommons.unl.edu/andrillrespub

Part of the Geochemistry Commons, Geology Commons, Geomorphology Commons, Glaciology Commons, and the Sedimentology Commons

lacoviello, Francesco; Giorgetti, Giovanna; Nieto, Fernando; and Memmi, Isabella Turbanti, "Evolution with depth from detrital to authigenic smectites in sediments from AND-2A drill core (McMurdo Sound, Antarctica)" (2012). ANDRILL Research and Publications. 55.

https://digitalcommons.unl.edu/andrillrespub/55

This Article is brought to you for free and open access by the Antarctic Drilling Program at DigitalCommons@University of Nebraska - Lincoln. It has been accepted for inclusion in ANDRILL Research and Publications by an authorized administrator of DigitalCommons@University of Nebraska - Lincoln. 
Published in Clay Minerals 47 (2012), pp. 481-498; doi: 10.1180/claymin.2012.047.4.07

Copyright (c) 2012 The Mineralogical Society. Used by permission.

Submitted March 1, 2012; revised May 27, 2012.

\title{
Evolution with depth from detrital to authigenic smectites in sediments from AND-2A drill core (McMurdo Sound, Antarctica)
}

\author{
F. Iacoviello, ${ }^{1}$ G. Giorgetti, ${ }^{1}$ F. Nieto, ${ }^{2}$ and I. T. Memmi ${ }^{1}$ \\ 1. Dipartimento di Scienze della Terra, Università degli Studi di Siena, Via Laterina 8, 53100 Siena, Italy \\ 2. Departamento de Mineralogía y Petrología and I.A.C.T., Universidad de Granada - CSIC, \\ Avenida Fuentenueva s/n, 18002 - Granada, Spain \\ Corresponding author - F. Iacoviello, email iacoviello3@unisi.it
}

\begin{abstract}
We have examined the nature and origin of smectites in glaciomarine sediments of the AND-2A drill core (McMurdo Sound, Antarctica) by means of X-ray diffraction (XRD) analyses on the clay fraction, field emission scanning electron microscopy (FESEM), scanning electron microscopy (SEM) observations and SEM-EDS microanalyses on smectite particles. Relying on the smectite variation throughout the drill core it was possible to split the sequence into three units. Smectites throughout the core are either detrital or authigenic. Detrital smectites are close to montmorillonite-beidellite in composition while newly-formed smectites frequently have higher Fe-Mg contents and intermediate compositions between the saponite and nontronite field, with lower amounts in the montmorillonite-beidellite field. In the upper sedimentary sections (Unit I, and Unit II, 36-440 mbsf, 0.7-16.5 Ma) smectites are interpreted to be predominantly detrital, whereas in the lower portion of the core (Unit III, 440-1123.20 mbsf, 16.5-20.2 Ma) authigenic smectites are the most common feature. The predominance of mica, the abundance of chlorite, and the nature of smectites in the upper units indicate physical weathering under cold and dry climate, and a dominant provenance for the clay minerals from the Transantarctic Mountains. Smectites in the lower unit are considered mostly authigenic and they are most likely to be the result of early diagenetic processes, being formed from the alteration of volcanic material (glass, pyroxenes and feldspars) and/or through precipitation from fluids of a possible hydrothermal origin. Our survey attests to the importance of discriminating between a detrital and authigenic nature of smectites as the occurrence of authigenic clay minerals in ancient sedimentary successions might lead to incorrect paleoclimatic interpretations, since they can be affected by diagenetic processes, thus obliterating the climatic signal.
\end{abstract}

Keywords: smectites, hydrothermal, volcanic, ANDRILL, McMurdo Sound, Antarctica, FESEM

The variation in smectite content in the Cenozoic and Quaternary sedimentary sequences in offshore Antarctica has been successfully employed to describe paleoclimatic and paleoenvironmental changes and to ascertain sediment source rocks (Chamley, 1989; Ehrmann, 1998; Ehrmann et al., 2005).
Interpretation of the genesis of smectite in marine sediments can be disputed because the mineral can be either detrital or authigenic. Detrital smectites derive from continental soils and parent rocks, whilst authigenic smectites often form in sea-floor sediments due to submarine weathering (halmyrolysis) of volcanic material (Biscaye, 1965; Kastner, 
1981; Chamley, 1989) and by direct precipitation from hydrothermal fluids (Moorby \& Cronan, 1983; Cole \& Shaw, 1983; Huertas et al., 2000). Only detrital smectites are indicative of paleoenvironment, provenance and transport (Chamley, 1989; Singer, 1984), while authigenic smectites can provide information on geochemistry of the sedimentary environment and on post-depositional changes during diagenesis.

The distinction between authigenic and detrital smectites is usually based on habit and chemical composition (Chamley, 1989; Singer, 1984; Hillier, 1995). Authigenic smectites usually occur as newly-formed phases on glass shards or volcanic minerals; they show hairy-shape features or honeycomb structures (Chamley, 1989; Buatier et al., 2002) and belong to the saponite and nontronite series (Setti et al., 2000; Ehrmann et al., 2005, Manuella et al., 2012). On the contrary, detrital smectites often belong to the aluminous montmorillonite-beidellite series and show flaky structures (Setti et al., 2000; Ehrmann et al., 2005). Nevertheless, montmorillonites and beidellites can also represent the product of neoformation from the hydrolysis weathering of primary minerals such as feldspars and muscovite (Fesharaki et al., 2007).

Several possibilities typically exist for the origin of authigenic smectites: alteration of volcanic rocks and glass (Hein \& Scholl, 1978; Kurnosov et al. 1982; Cole \& Shaw, 1983; Do Campo et al., 2010), direct precipitation from hydrothermal fluids, the lowtemperature combination of Fe-oxyhydroxide and biogenic silica (Cole, 1985; Chamley, 1989 and reference therein; Cuadros et al. 2011) or early diagenesis, are probable mechanisms through which smectite could have formed.

The AND-2A drill site is situated in an ice-proximal position in the southern part of McMurdo Sound, $\sim 30 \mathrm{~km}$ west of McMurdo Station $\left(77^{\circ}\right.$ $45.488^{\prime} \mathrm{S}$; $165^{\circ} 16.613^{\prime} \mathrm{E}$, Figure 1), where the depositional system is influenced by the East Antarctic Ice Sheet outlet glaciers to the west and by the Ross Ice Shelf to the south. The AND-2A core was drilled down to $1138.54 \mathrm{~m}$ below the sea floor (mbsf) at the southern margin of the Victoria Land Basin (Harwood et al., 2009) and recovered sediments which span from $20 \mathrm{Ma}$ to the present in age.

In this survey the morphological and compositional features of the smectites of the AND-2A core have been examined in detail and also compared with smectites of other sedimentary sequences from the McMurdo Sound.
Textural and morphological analysis by scanning electron microscopy is essential for recognizing diagenetic reactions (such as smectite authigenesis) and for identifying reworked clay minerals, and thus for determining whether the clay mineral assemblages could be interpreted in terms of paleoclimate. In order to determine the relative importance of volcanic and climatic factors, and to avoid erroneous interpretations, we present an integrated approach using $\mathrm{X}$-ray diffraction, scanning electron microscopy, and field emission scanning electron microscopy analyses of fine-grained samples.

\section{Study Area and Geological Background}

The southern McMurdo Sound is delimited to the west by a sector of the Transantarctic Mountains (TAM), a $4 \mathrm{~km}$ high mountain range acting as an obstacle to the direct flow of the East Antarctic Ice Sheet into the Ross Sea, and largely uplifted starting at $\sim 55 \mathrm{Ma}$ as a consequence of the west Antarctic Rift System evolution (Fitzgerald, 2002). On the other hand, the southern and eastern sides are characterized by extensive volcanic centers belonging to the Cenozoic alkaline McMurdo Volcanic GroupErebus Volcanic Province (Kyle, 1990; Figure 1).

The Transantarctic Mountains are composed of a Late Precambrian to Early Paleozoic crystalline basement which formed during the Ross Orogeny and mostly outcrop along the coastal area, overlain by a cover complex confined to the inner part of the on-shore region (Figure 1; modified after Giorgetti et al., 2009).

The stratigraphy of AND-2A relies on a combination of biostratigraphy, magnetostratigraphy and radiogenic isotope dating of tephra and other volcanic materials (Acton et al., 2008-2009). Three distinct stratigraphic intervals separated by major disconformities have been recognized (Acton et al., 20082009, with modifications reported by the ANDRILL SMS Science Team, 2010): (1) an Early Miocene succession (from bottom of the core to $\sim 300 \mathrm{mbsf}$ ); (2) a Middle Miocene interval (from $\sim 300$ to $225 \mathrm{mbsf}$ ) characterized by a well constrained age model; and (3) a Late Miocene to Pliocene succession (from 225 mbsf to the top of the core) with several hiatuses which represent a total 9 to 11 million years of time missing from the sedimentary sequence record (Harwood et al., 2009; Acton et al., 2008-2009, with modifications reported by the ANDRILL SMS Science Team, 2010). 


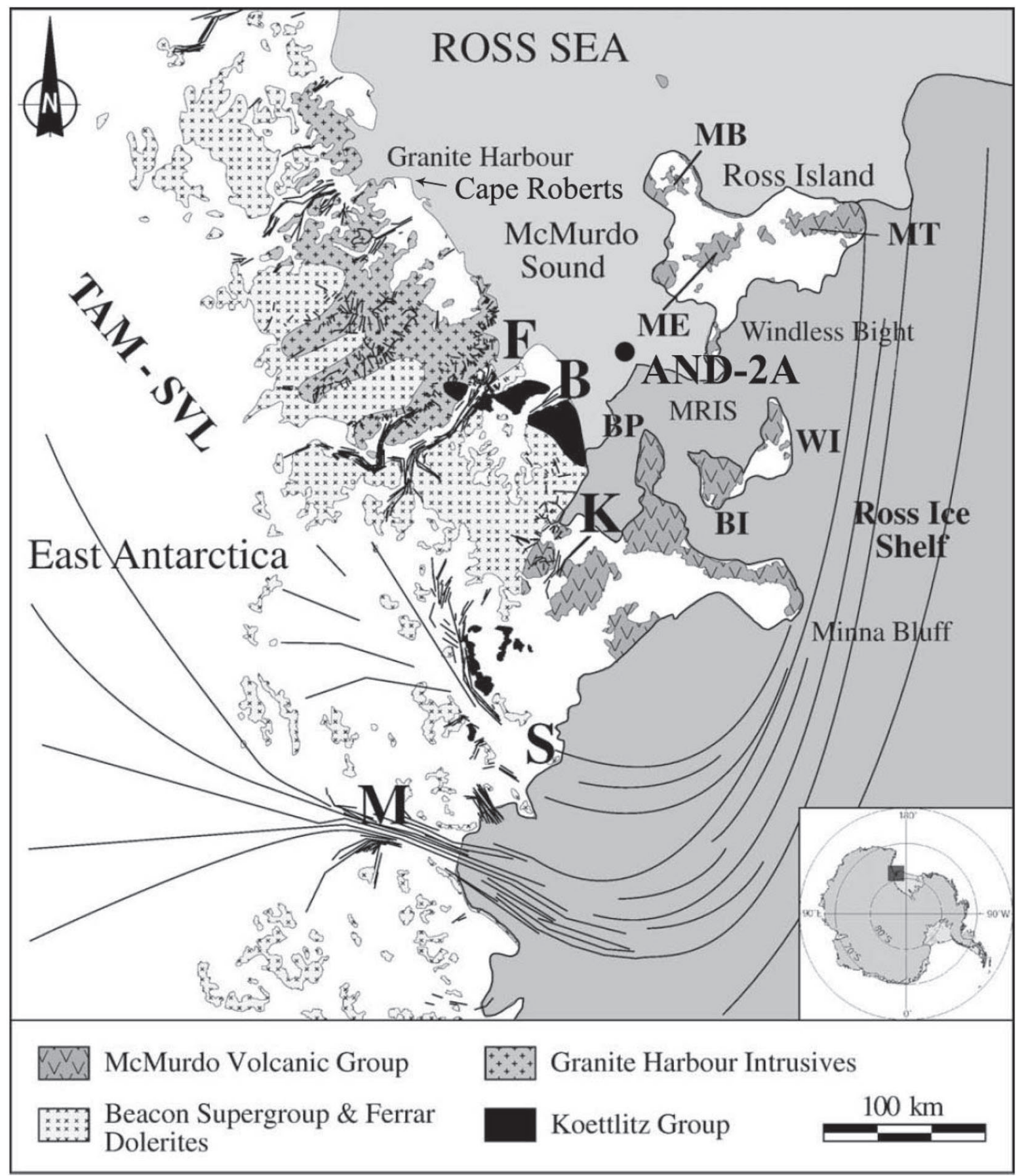

Figure 1. Map of the McMurdo Sound area. The filled grey square on Antarctica refers to the enlarged picture. Dot, drill site; MRSI, McMurdo/Ross ice shelf; TAM-SVL, Transantarctic Mountains, Southern Victoria Land; F, Ferrar Glacier; B, Blue Glacier; K, Koettlitz Glacier; S, Skelton Glacier; M, Mulock Glacier; BP, Brown Peninsula; WI, White Island; BI, Black Island; ME, Mt Erebus; MT, Mt Terror; MB, Mt Bird. Koettlitz Group mainly outcrops between the Skelton and the Koettlitz area. Lines indicate the modern ice flow (see Bentley, 1998; Denton \& Hughes, 2000). 
The recovered glaciomarine succession is subdivided into fourteen lithostratigraphic units (LSUs), including thirteen lithofacies (Fielding et al., 2008-2009, 2011), which range from rare diatomites to diamictites and conglomerates (representing most ice-distal and most ice-proximal environments, respectively, Fielding et al., 2011; Passchier et al., 2011). The sedimentary succession also contains sandstones and mudrocks, volcanic lava, pyroclastic and reworked volcanic sedimentary rocks, proving that volcanic material is persistent throughout the AND-2A core; it is the dominant clast type $(>50 \%)$ in nine of the 14 lithostratigraphic units and includes, in order of relative abundance, volcanic sediments, juvenile magmatic clasts (i.e. pyroclasts) and lava (Panter et al., 2008-2009).

Volcanic glass is a prominent component and ranges from blocky and cuspate brown mafic shards to long tube white pumice and blocky alkaline green shards. The glass composition changes down core. Brown mafic glass is present in all of the samples examined down core. White pumice glass comes in at LSU 4 at 125 mbsf. Alkaline green glass is added $\sim 450 \mathrm{~m}$ down the core in LSU 8.1 (Panter et al. 2008-2009).

The sediments between 1138.54 and $\sim 440$ mbsf consist of an alternation of diamictite-dominated units and units dominated by siltstones and sandstones. Within this succession a homogeneous and thick mudstone unit occurs at 900-780 mbsf. Between $\sim 440$ and 36 mbsf the core is characterized mainly by thick diamictites and thin intercalated sandstones. A zone of finer grained lithologies with some diatomites occurs within the sequence at 340300 mbsf. Mixed volcanic rocks form the top of AND-2A above 36 mbsf (Fielding et al., 2008-2009, 2011; Del Carlo et al., 2009; Di Vincenzo et al., 2010).

\section{Materials and Methods}

A total of 169 sediment samples of the AND-2A core, starting from $36 \mathrm{mbsf}$ to $1123.20 \mathrm{mbsf}$, were analyzed for their clay mineral composition by XRD. Sample spacing was approximately $6 \mathrm{~m}$.

For each sample, $10 \mathrm{~cm}^{3}$ of sediment were crushed, then washed by double centrifugation with $400 \mathrm{ml}$ of deionized water in order to remove halite $(\mathrm{NaCl})$. They were further gently disaggregated by magnetic stirrer agitation for $30 \mathrm{~min}$ per sample and sieved through a $63 \mu \mathrm{m}$ sieve. Separation of the clay fraction $(<2 \mu \mathrm{m})$ was achieved through Stokes' law settling procedures in glass tubes and the analyses were performed following standard procedures (Ehrmann et al., 1992; Petschick et al., 1996). XRD measurements were conducted on texturally oriented samples with an automated Philips PW1710 powder diffraction control system, coupled with a PW1820 generator, using $\mathrm{Cu}-\mathrm{Ka}$ radiation $(40 \mathrm{kV}, 20 \mathrm{~mA})$. Each sample was analyzed between $4^{\circ} 2 \theta$ and $40^{\circ} 2 \theta$, with a step size of $0.02^{\circ} 2 \theta$, in the air-dry state and after ethylene glycol solvation. In addition, a slow scan, between $23^{\circ} 2 \theta$ and $25.5^{\circ} 2 \theta$, with a step size of $0.005^{\circ} 2 \theta$, was performed on the ethyleneglycolated samples to achieve a better resolution of the chlorite (004)-kaolinite (002) twin peak. The diffractograms were processed using "MacDiff" software (Petschick, 2001), which permits a rapid deconvolution of peaks for the separation of contributions of minerals with similar spacing, such as kaolinite and chlorite. The abundance of the principal clay minerals (smectite, illite, chlorite and kaolinite) was semi-quantitatively estimated by calculating the peak areas of their main basal reflections in the glycolated state: smectite at $17 \AA$, illite at 10 and $5 \AA$, chlorite at $14.2,7$ and $3.54 \AA$ and kaolinite at 7 and $3.57 \AA$ (Petschick et al., 1996). The percentages of each clay mineral were computed using empirically estimated weighting factors on the integrated peak areas of the individual clay mineral reflections (Biscaye, 1965). Clay mineral percentage standard deviations were calculated to be: illite $\pm 1 \%$, smectite $\pm 1 \%$, chlorite $\pm 2.5 \%$ and kaolinite $\pm 2 \%$.

Scanning electron microscope observations and chemical microanalyses were carried out on 40 selected polished thin sections using a Philips ${ }^{\circledR}$ XL30 device operated at $20 \mathrm{kV}$ and equipped with an EDAX energy-dispersive (EDS) X-ray spectrometer (Dipartimento di Scienze della Terra, University of Siena). Energy-dispersive microanalyses have been used to calculate the structural formulae of smectites on the basis of $\mathrm{O}_{10}(\mathrm{OH})_{2}$.

Field emission scanning electron microscope investigations were carried out on ten rock chip selected samples by a LEO (Carl Zeiss) 1530 GEMINI (Centro de Instrumentación Científica, University of Granada, CIC) operated at $10 \mathrm{kV}$ and equipped with an Oxford INCA 200 microanalysis system. FESEM allows higher magnification (up to $900 \mathrm{k} \times$ ) compared to traditional SEM and thus yields better resolution of clay particle micromorphologies. Sediment samples for SEM and FESEM investigations 
were selected on the basis of their clay mineral percentage distribution. In order to achieve a coherent investigation, we chose samples of different lithology (diamictites, sandstone, mudstones and volcanic-bearing diamictites) and for each lithology, samples with high smectite content, similar smectite-illite ratios and low smectite content.

\section{Results}

\section{Clay mineral distribution}

The most abundant clay minerals in sediments of the AND-2A drill core are illite and smectite. Illite content ranges between 0 and $91 \%$ and it is negatively correlated $\left(R^{2}=-0.93\right)$ with smectite content (which ranges between 1 and 100\%). Chlorite is seldom more than $30 \%$ and kaolinite is absent or present only in traces $(<4 \%)$.

Figure 2 shows the down-core clay mineral variations. Due to these variations it was possible to distinguish three units. In Unit I (36-225 mbsf, 0.7$15 \mathrm{Ma})$ smectite and illite are reasonably constant (average of 35 and $41 \%$ respectively) and chlorite shows large fluctuations. In Unit II (225-440 mbsf, 15-16.5 Ma) the smectite content decreases (average of $9 \%$ ) and the illite content increases (average of $72 \%$ ), while chlorite decreases slightly and shows lower fluctuations. Unit III (440-1123 mbsf, 16.5$20.2 \mathrm{Ma}$ ) is characterized by large smectite-illite fluctuations, while chlorite displays moderate fluctuations with an average value of $14 \%$.

These results are in agreement with those reported by Franke \& Ehrmann (2010) for the same drilling-core, although with slight differences in clay mineral percentages.

\section{Smectite morphology and composition}

Scanning electron microscope and FESEM observations on the clay mineral fraction showed that the smectites of AND-2A sediments display both hairy and honeycomb structures (Vitali et al., 1999; Ehrmann et al., 2005, Fesharaki et al., 2007) as well as flaky shapes; such forms have also been recognized in the CRP-1, 2, 3 cores and in other records from the Ross Sea (Setti et al., 1997, 1998, 2000; Ehrmann, 2000, 2001; Ehrmann et al., 2003). Flaky shapes are considered to be of detrital origin and are mostly typical of alkaline smectites or beidellites, forms usually found in soils. Hairy and honeycomb smectites frequently occur in marine sediments. Because of their morphology, these shapes are fragile and have been considered to be authigenic (Chamley, 1989; Vitali et al., 1999; de la Fuente et al., 2000; Ehrmann et al., 2005, Fesharaki et al., 2007). We define authigenic smectites as those crystals that coat grains, that replace other minerals or grow over them and that showed hairy shape or honeycomb structures. Detrital smectites are more difficult to identify because they do not show such peculiar features. However, we define detrital smectites as those crystals in the finegrained matrix showing no textural relation with glass or other volcanic fragments and that present platy morphologies.

Figures $3 \mathrm{a}$ and $3 \mathrm{~b}$ show both detrital and authigenic smectites from sample 124.97 mbsf (Unit I). Figure 3a displays authigenic smectites that completely replace a glass shard. In the upper portion of the image detrital smectites are also present. Figure $3 \mathrm{~b}$ shows a FESEM-SE image of the same sample; a flaky structure typical of detrital origin is easily recognized. A platy morphology of smectites is clearly observable and some crystallites show rounded edge shapes. Such structures are very similar to other ones interpreted by Ehrmann et al. (2005) as detrital.

Figures $3 \mathrm{c}$ and $3 \mathrm{~d}$ show authigenic smectites from sample 315.00 mbsf (Unit II). We observed crystals of K-feldspars (3c) and pyroxenes (3d) that constitute the parent material for authigenic smectites. This fact is in agreement with experimental studies by Drief et al. (2001), who demonstrated that the alteration mechanism and the sequence of feldspar transformation into clays are controlled by dissolution-reprecipitation processes. These authors also showed that the chemical nature of the newly formed smectite is determined by the composition of the parent mineral.

Detrital smectites usually constitute the matrix of the sediments (Figure 3e). On the contrary, authigenic smectites occur as coating on detrital grain or develop in pore cavities (Figure 3f).

Figures $3 \mathrm{~g}$ and $3 \mathrm{~h}$ display authigenic smectites of Unit III from samples 775.00 and 1113.02 respectively. Figure $3 \mathrm{~g}$ shows hairy shape smectites replacing a highly altered glass shard.

FESEM investigations emphasize smectite features that are clearly different from those observed in Figure 3b. In particular, we observed a feldspar grain with a typical honeycomb shape (Figure 3h), 


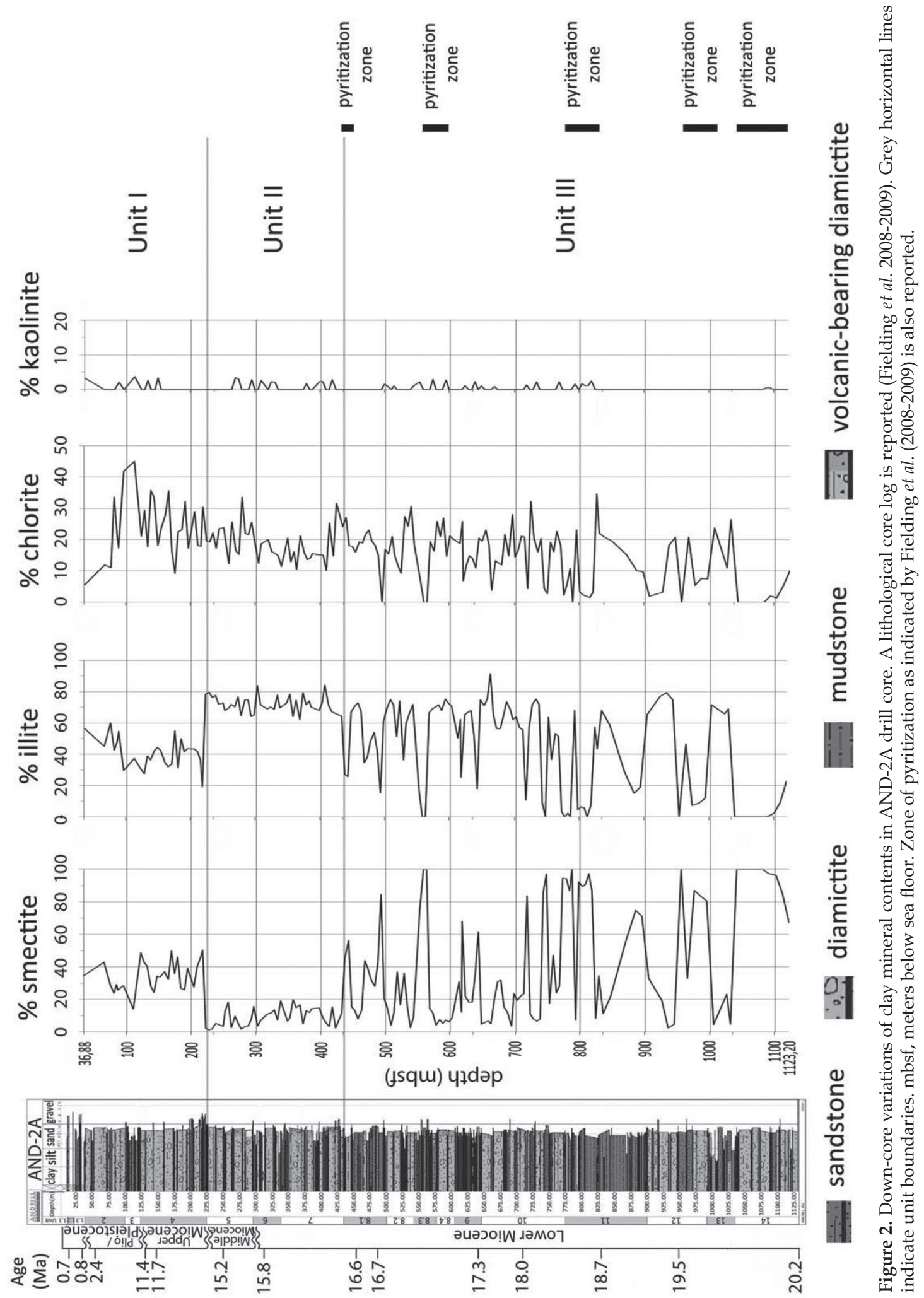


a characteristic feature of newly-formed smectites; in contrast to the flaky feature typical of detrital smectites, honeycomb shapes show warped edges and a very delicate structure. Our morphologic investigations are very similar to those obtained by Fesharaki et al. (2007); these authors recognized the partial dissolution of feldspars with honeycomb smectite of montmorillonitic composition grown on them.

In Table 1 the chemical compositions of smectites in the AND-2A drill core are reported. An authigenic or detrital origin has been assigned to the analyzed smectites taking into account their morphological features. In polished thin section, authigenic smectites are easily recognizable because they occur as radial rims around grains or with a filamentous shape (hairy shape). A combined SEM-FESEM observation was needed to ascertain quite clearly the detrital nature of the smectites.

The composition of the smectites is extremely variable, ranging from $\mathrm{Al}$-rich smectites to $\mathrm{Mg}$ Ferich smectites. In each unit, smectites are characterized by the presence of $\mathrm{Al}$ in both tetrahedral and octahedral sites and by variable substitution of $\mathrm{Fe}^{3+}$ and $\mathrm{Mg}$ for octahedral Al. Fe was assumed to be all ferric, since $\mathrm{Fe}^{2+}$ in smectite oxidizes very quickly when exposed to the atmosphere (Decarreau \& Bonnin, 1986).

In Figure 4, the octahedral composition ( ${ }^{\mathrm{VI}} \mathrm{Al}-$ ${ }^{\mathrm{VI}} \mathrm{Mg}_{-}{ }^{\mathrm{VI}} \mathrm{Fe}$ diagram) of the smectites was plotted with respect to the three units. The usual smectite grain size is smaller than the spatial resolution of analyses by SEM; therefore most of the analyses probably represent the composition of a smectitic area than that of an individual smectite grain. In spite of this fact, in each unit two distinct compositional trends can be recognized: detrital smectites show an Al-richer compositions, close to the montmorillonite-beidellite field; authigenic smectites have higher Fe-Mg contents and intermediate compositions between the saponite and nontronite field. Some authigenic smectites on feldspar grains show relatively higher Al-rich composition, close to the montmorillinitic-beidellitic composition.

Some of the analyses presented in Table 1 show high interlayer charge and/or low Si content. Such chemical characteristics could be a consequence of contamination by illite or chlorite due to the size of the analyzed area in relation to the small grain size of smectite, but they also could represent illite or illite/smectite interstratified minerals. Furthermore, as already mentioned, detrital smectites were identified in the fine-grained matrix, and contamination by $\mathrm{Ca}, \mathrm{Na}$ or $\mathrm{K}$ from other phases present in the matrix (e.g. small calcite grains, plagioclase and Kfeldspars) can occur. This could explain why some of the detrital smectite analyses show an interlayer charge $>1$.

Figure 5 shows a frequency histogram of octahedral site occupancy of detrital and authigenic smectites. Detrital smectites belong predominantly to class 1.90-2.09, thus confirming the dioctahedral nature of this phyllosilicate. On the contrary, authigenic smectites show a more variable behavior and most of the values fall into class 2.50-2.69; our data probably represent analyses of intimately mixed species (Abad et al., 2003; Jiménez-Millán et al., 2008), therefore representing mixed compositions with a predominant trioctahedral character. Authigenic smectites have an intermediate composition between the dioctahedral and trioctahedral fields and a minor number of analyses clearly corresponding to dioctahedral compositions. The limit between the detrital and authigenic smectitic areas seems to fall in the class 2.10-2.29.

Figure 3 (page 488). SEM and FESEM images of authigenic and detrital smectite from Units I and II. SEM-BSE image a shows a glass shard completely replaced by authigenic smectite (Sm, white arrows); in the upper part of the image detrital smectites (Sm) are shown (sample 124.97 mbsf, Unit I). b shows a FESEM-SE image of detrital smectites (Sm) from sample 124.97 mbsf (Unit I). c shows a SEM-BSE image displaying smectite assemblages (Sm) of neoformation origin from sample 315.00 mbsf (Unit II). d (SEM-BSE) shows neoformation smectite replacing a pyroxene (Px) in sample $315.00 \mathrm{mbsf}$ (Unit II). Mineral abbreviations after Kretz (1983). SEM and FESEM images of authigenic smectite from Unit III. SEM-BSE image e displays detrital smectite assemblage (Sm, white arrows), in sample 695.95 mbsf. f (SEM-BSE) shows a hairy shape feature characteristic of authigenic smectites (Sm, white arrows) in sample 749.99 mbsf. g (SEM-BSE) displays a partial replacement of a glass shard by newly formed smectite (Sm, white arrows) in sample 775.00 mbsf. h shows a FESEM-SE image displaying honeycomb structure characteristic of authigenic smectite (Sm) from sample 1113.02 mbsf. Mineral abbreviations after Kretz (1983) except gl: glass. 

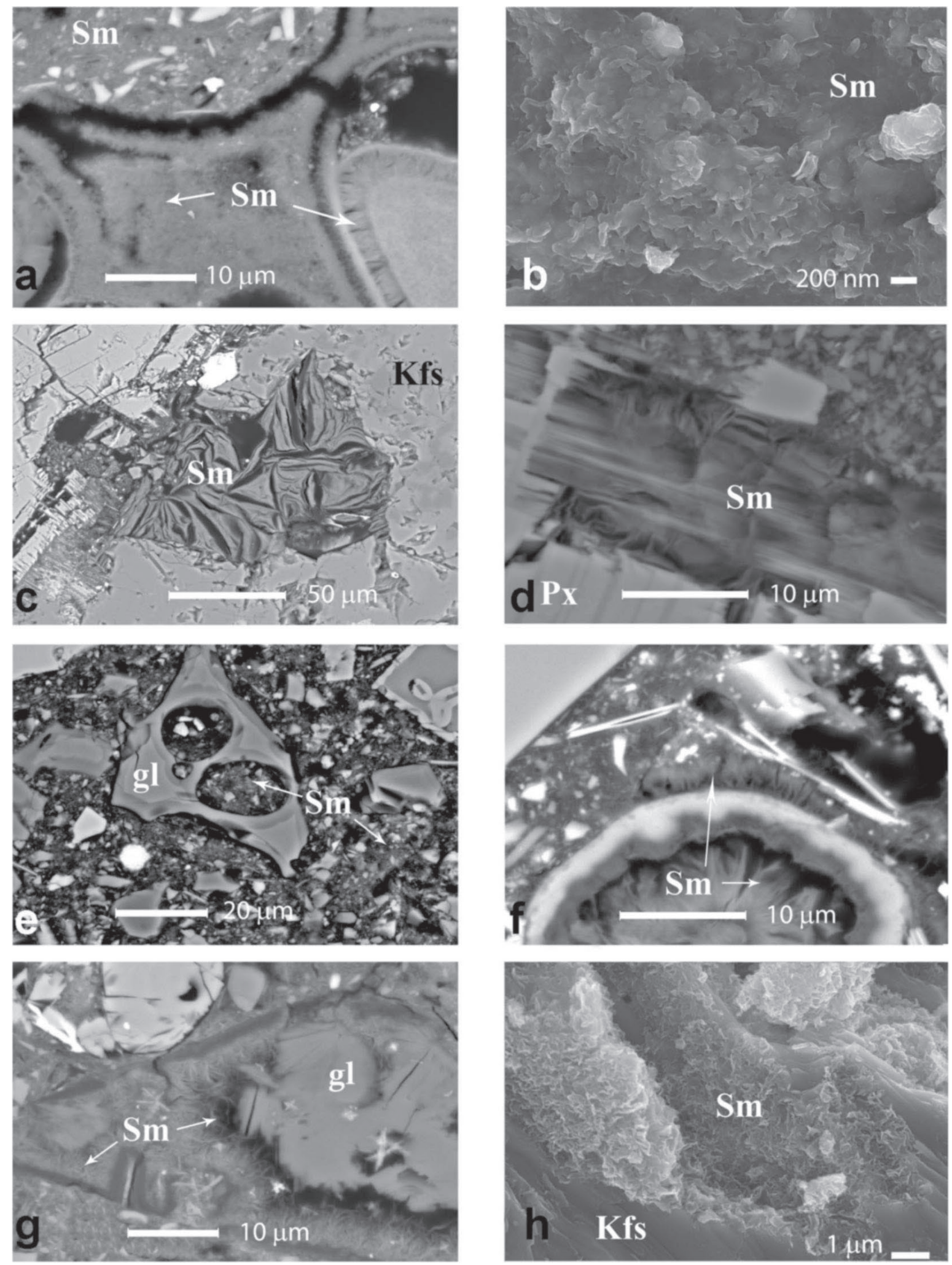

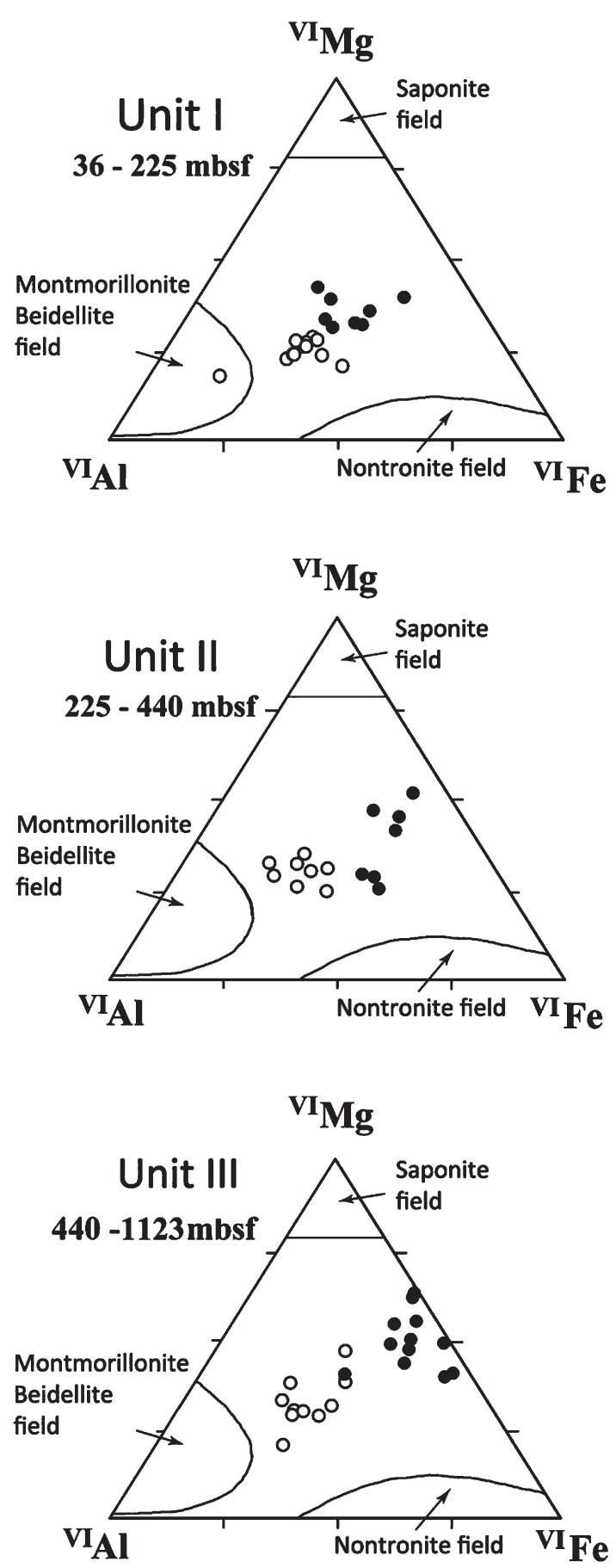

Figure 4. Ternary $\mathrm{Al}^{\mathrm{VI}}-\mathrm{Mg}-\mathrm{Fe}$ diagram of octahedral site composition of the smectites from different units (black circles indicate authigenic smectites, while white circles display detrital smectites). The montmorillonite-beidellite field usually includes detrital smectites, while the saponite and nontronite fields comprise authigenic phases.
Figure 6 shows the evolution of the chemical composition of smectites with depth. An increase of the trioctahedral character from top to the bottom of the sequence can be recognized by the higher $\mathrm{Mg}$ content and particularly by the increase of octahedral site occupancy. The change in Fe content is less obvious, the chemical change with depth affecting the saponitic component more than the nontronitic component. The most significant change in composition is concentrated in the range between 400 and 600 mbsf (Figure 6).

\section{Discussion and Conclusion}

The clay mineral assemblage of sediments from the AND-2A drill core is dominated by smectite and illite with minor chlorite and traces of kaolinite. Smectite and illite show the greatest variations in relative proportions.

In marine sediments, clay mineral assemblages are mainly controlled by source rock compositions, physical-chemical weathering, transport and depositional mechanisms (Biscaye, 1965; Ehrmann et al., 1992; Diekmann et al., 1996). Source areas and the type of weathering control the different clay mineral assemblages, while transport and sedimentation mechanisms may cause a selective enrichment of the different mineralogical phases. Consequently, clay minerals from Antarctic marine sediments have been interpreted as reflecting changes in source areas as tracers of paleo-ice stream directions (Petschick et al., 1996), as a check on weathering styles in respect to paleoclimatic changes (Ehrmann \& Mackensen, 1992; Ehrmann, 1998), and for paleoceanographic reconstructions (Diekmann et al., 1996). Recent studies on clay minerals in the sequences collected near Cape Roberts have attempted to discriminate detrital and authigenic clay minerals (Setti et al., 2001, 2004; Wise et al. 2001; Ehrmann et al., 2005; Giorgetti et al., 2007), as only detrital clays can be used as paleoclimatic indicators. Conversely, authigenic clay minerals may provide indications of post-sedimentary processes and geochemical conditions of evolution (Chamley, 1989; Weaver, 1989; Setti et al., 2004; Ehrmann et al. 2005). Franke \& Ehrmann (2010) carried out a semi-quantitative analysis of the clay mineral assemblages in sediments from the ANDRILL AND-2A drill core, but they did not focus on a detailed and systematic observation of authigenic and detrital smectites and on their chemistry. The occurrence of authigenic clay minerals may in fact lead to incorrect paleoclimatic in- 


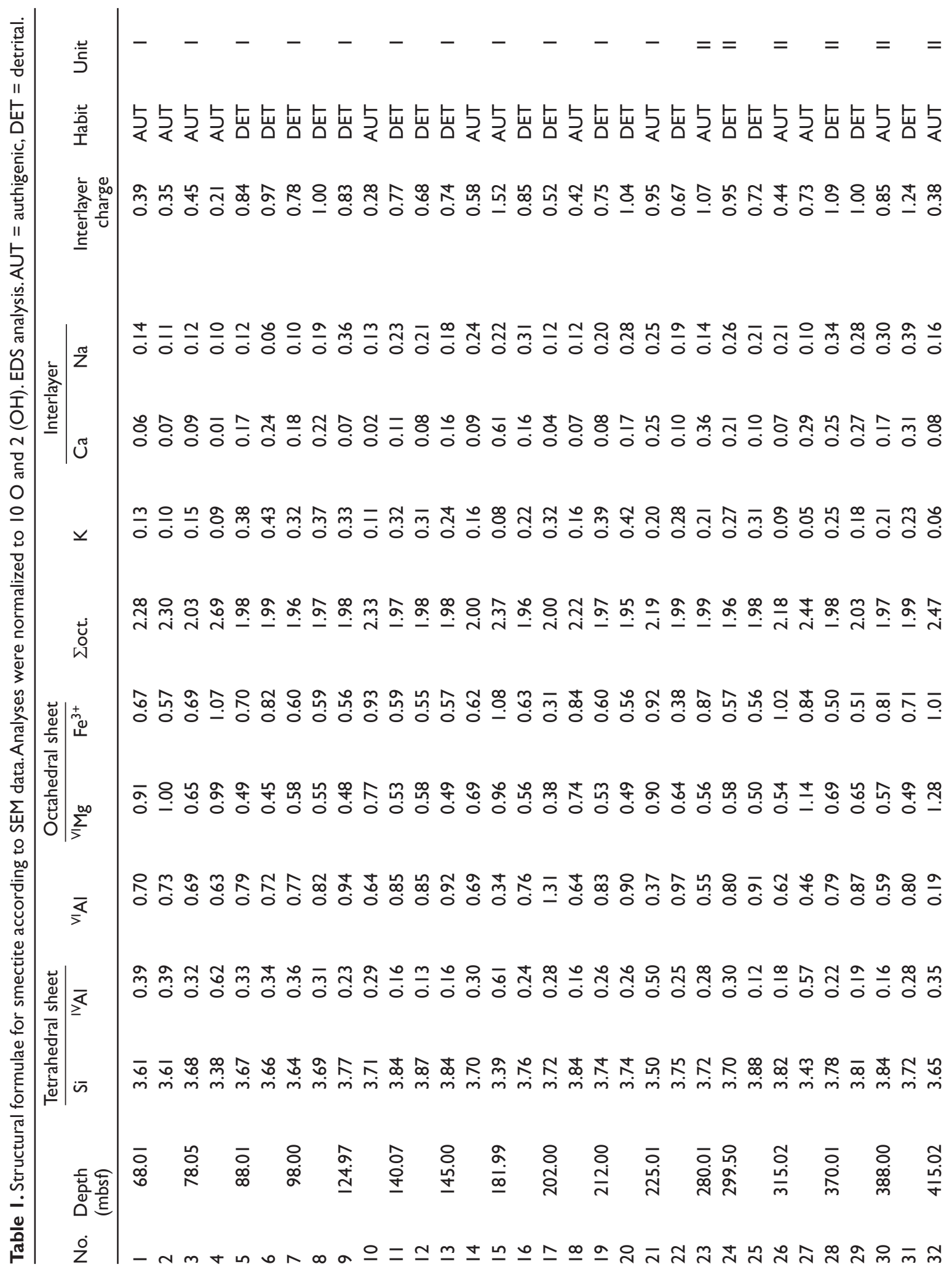




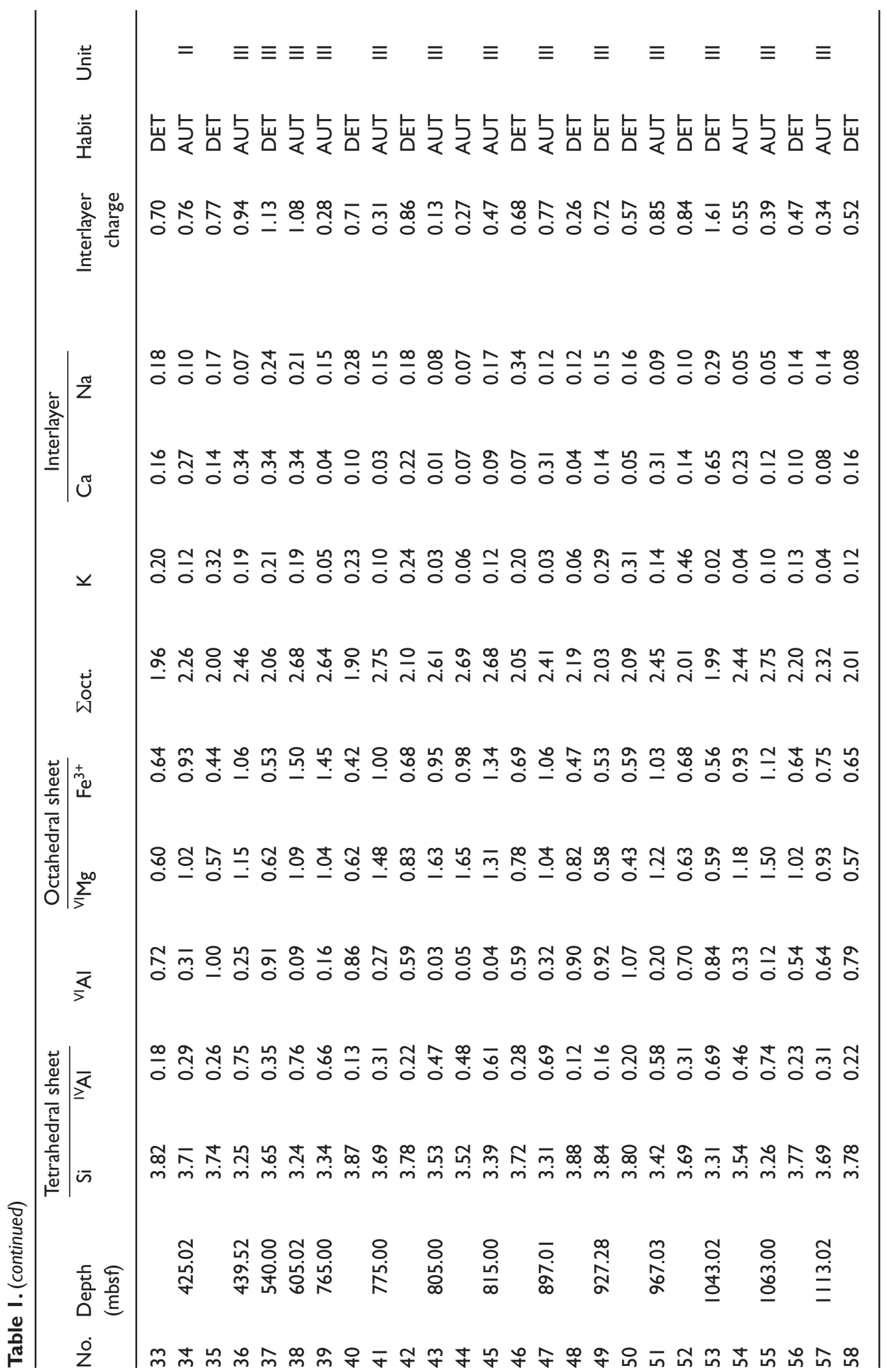




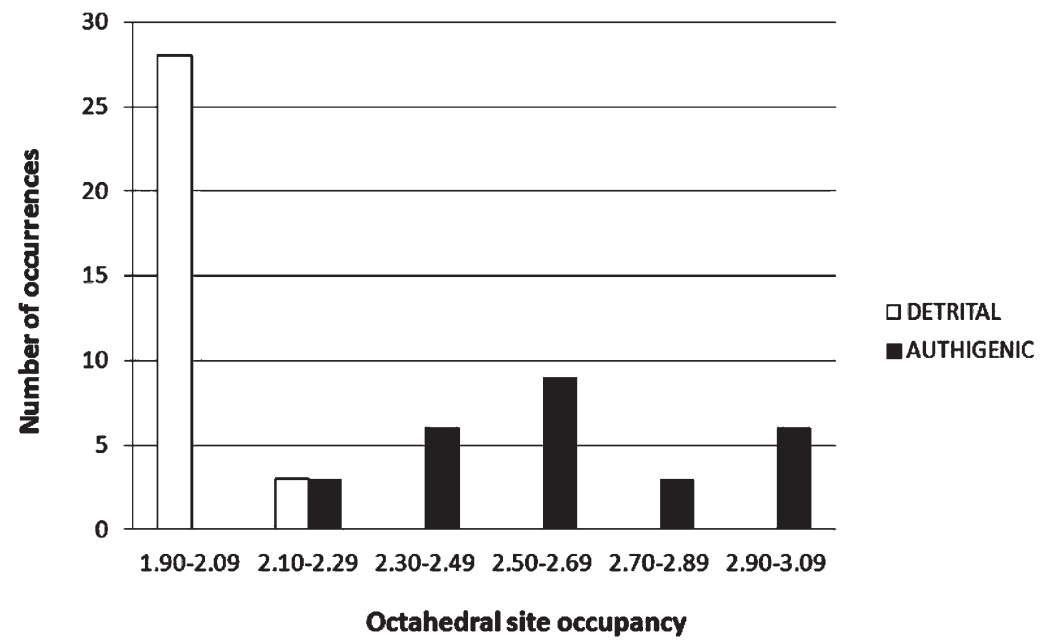

Figure 5. Frequency histogram of octahedral site occupancy of detrital and authigenic smectites.

terpretations (Do Campo et al., 2010). Therefore we focused on differentiating between detrital and authigenic phases.

In the upper part of the sedimentary sequence, corresponding to Unit I (36-225 mbsf) and Unit II (225-440 mbsf), smectites are both detrital and authigenic; the detrital ones have a chemistry close to the montmorillonite and beidellite field, showing a flaky structure, generally considered of detrital origin (Setti et al., 2000; Ehrmann et al., 2005). Most of the authigenic smectites show Mg-Fe-rich compositions associated with hairy shape and honeycomb feature, regarded to be of neoformation origin (Chamley, 1989; Buatier et al., 2002).

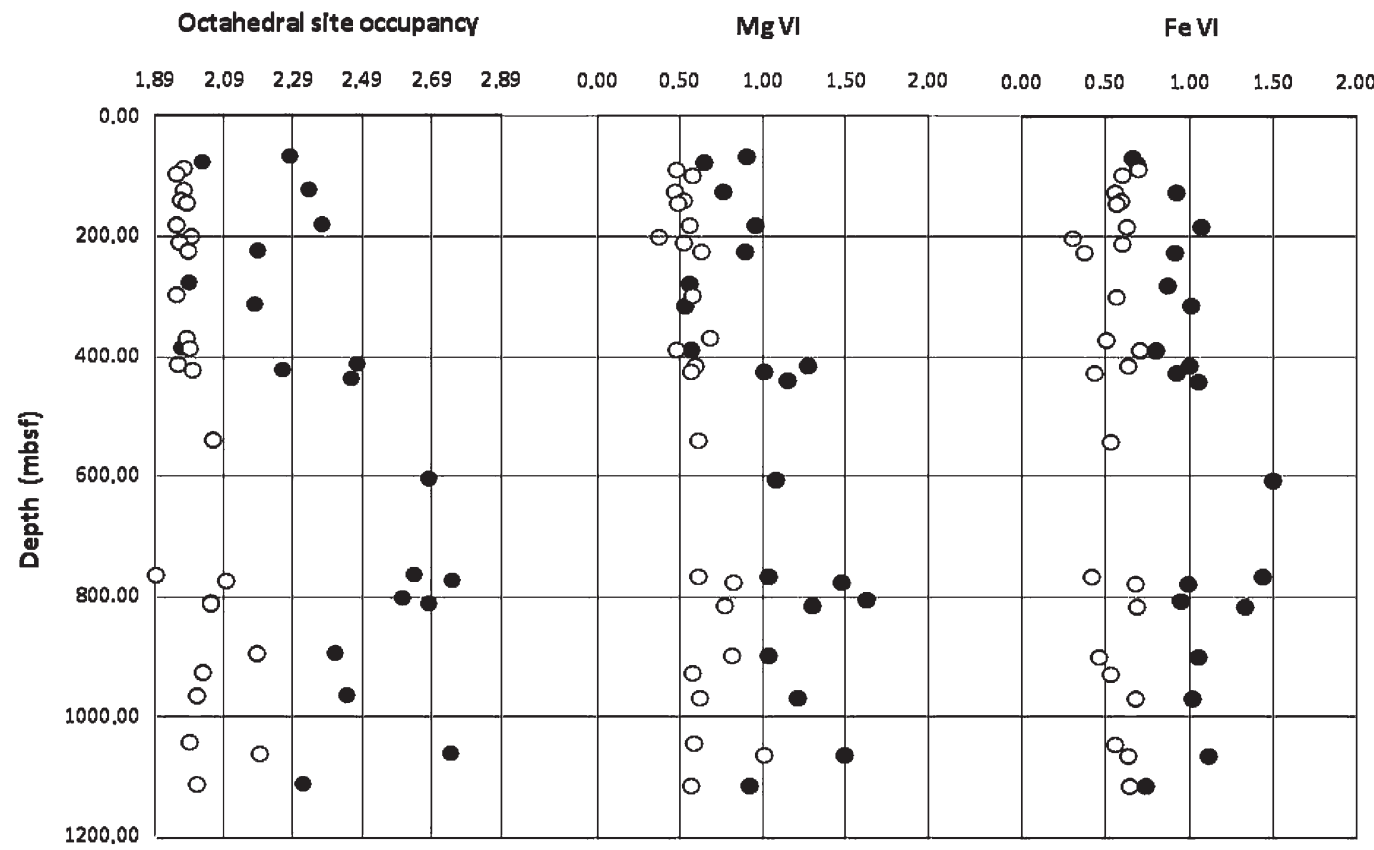

Figure 6. Plot of the chemical composition of smectites with depth (black circles indicate authigenic smectites, white circles display detrital smectites). 

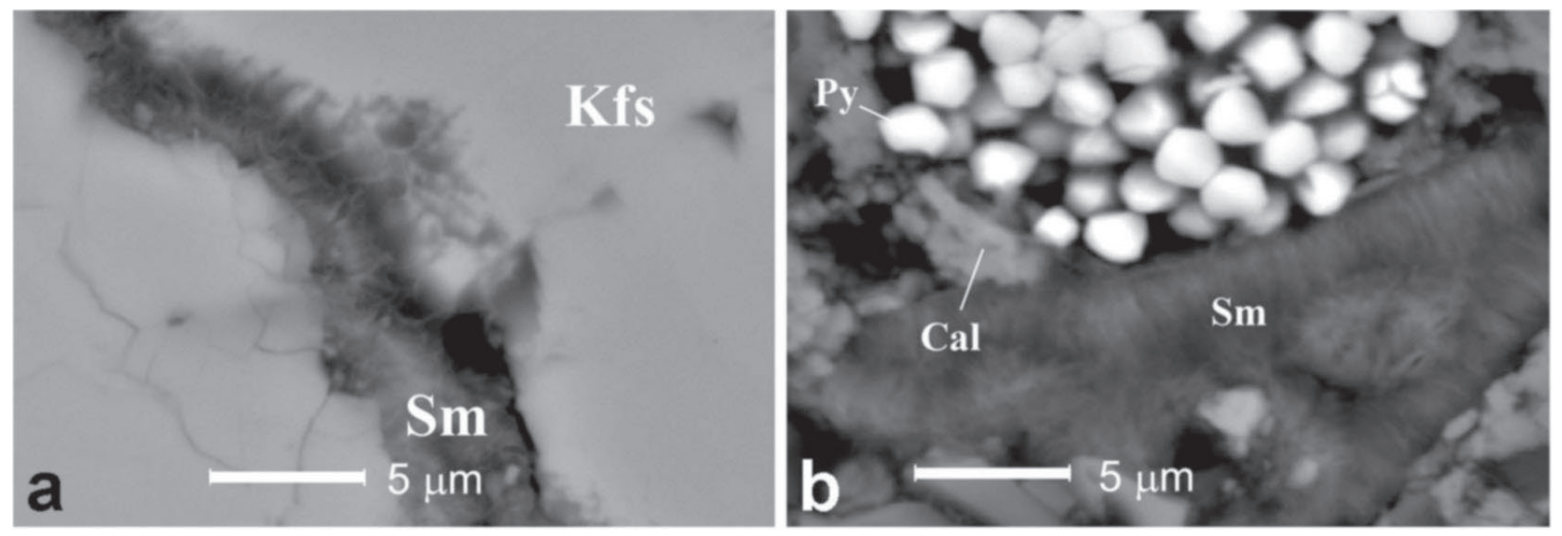

Figure 7. (a) SEM-BSE image showing a fracture in a K-feldspar grain (Kfs) filled by hairy shape smectite (Sm) of authigenic origin in sample 775.00 (Unit III). Mineral abbreviations after Kretz (1983). (b) SEM-BSE image of sample 825.80 (Unit III) showing a newly-formed hairy shape smectite $(\mathrm{Sm})$ in association with framboidal pyrite (Py) and authigenic calcite (Cal). Mineral abbreviations after Kretz (1983).

In the lower part of the drill core, Unit III (4401123 mbsf), detrital and authigenic smectites are also recognized displaying the same morphologic features of smectites from Unit I and II, while the chemistry of both detrital and authigenic smectitic areas seems to change slightly, starting from $\sim 440$ mbsf (Figure 6).

Detrital and authigenic smectitic areas from Unit III show a slightly lower content of $\mathrm{Al}$ and the chemical composition of authigenic smectite is closer to the saponite-nontronite series, which implies that the proportion of $\mathrm{Mg}$-rich and Fe-rich smectites in the analyzed areas has increased in relation to that of beidellite-montmorillonite. However, the composition of honeycomb authigenic smectites grown on feldspar grains (i.e. $1113.02 \mathrm{mbsf}$ ) is richer in $\mathrm{Al}$, which is related to the influence of the parent material on the chemical nature of the newly formed smectite (Drief et al., 2001).

The increase in $\mathrm{Mg}$ and Fe-rich smectite in respect to Al-rich smectite may be explained by a different fluid circulation regime, and/or by early diagenesis. Evidence for the fluid circulation hypothesis can be found in the presence of fractures, generally filled by authigenic smectites (Figure 7a), and iron sulfide (pyrite) formation of probable early diagenetic origin (Figure $7 \mathrm{~b}$ ). This scenario is coherent with a mechanism of fluid circulation proposed by other authors who carried out textural investigations on authigenic smectites in the CRP-3 Project (Wise et al., 2001; Giorgetti et al., 2007). In particular, Giorgetti et al. (2007) found that authigenic clay assemblages do not change downcore, but they do vary in chemically different rocks, i.e. newly formed dioctahedral smectites occur in sediments, whereas newly formed trioctahedral smectites are dominant in mafic rocks. Manuella et al. (2012) found that saponite-rich clays of the Hyblean Plateau (Sicily, Italy) were produced by the mixing of high-temperature hydrothermal fluids with cold seawater.

Pyrite is a common mineral product of early diagenesis in organic-rich sediments. It results from the reaction of sulfide (produced via bacterial sulfate reduction; Berner, 1970, 1980) with either $\mathrm{Fe}^{3+}$ in sediments or $\mathrm{Fe}^{2+}$ produced by bacterial $\mathrm{Fe}^{3+}$ reduction (Lovley, 1991).

Fielding et al. (2008-2009) found during core description, using smear-slide analysis and thin section petrography, that pyrite is almost absent above 430 mbsf, but it becomes common to abundant at greater depths. In some intervals ( 555-597 mbsf; $\sim 775-828$ mbsf; 958-1011 mbsf and below 1043 mbsf) pyrite imparts a black color to the sediments and obscures primary sedimentary features. In addition, below $\sim 440$ mbsf a coarser form of pyrite occurs alone or in association with calcite and other minerals within late-stage fractures.

Our findings confirm the observations on the AND-2A drill core by Fielding et al. (2008-2009); SEM investigations enabled us to identify pyrite in association with newly-formed smectite and calcite (Figure 7b). It is noteworthy that the higher smectite contents occur in the zone of pyritization (Figure 2) described by Fielding et al. (2008-2009). In 
these intervals authigenic smectite close to saponitic-nontronitic in composition are also predominant, thus confirming a possible correlation to fluid circulation and to early diagenetic processes.

The upper part of the sedimentary succession, corresponding to Unit I and Unit II, is characterized by a lesser influence of diagenetic processes, as testified by the low percentage of diagenetic calcite observed in smear-slide analysis by Fielding et al. (2008-2009) and the absence of diagenetic pyrite. In these two units, illite and chlorite, which are detrital clays, reach the highest content. These features indicate the dominant detrital nature of these sediments and the near absence of diagenesis in the upper part of the core.

Another significant change in the behavior of the smectite/illite ratio along the stratigraphic column is that Units I and II show a quite stable ratio in general, with a relatively low smectite content and higher illite content, but in Unit III the changes in the ratio are abrupt from sample to sample. Furthermore, in Unit III the samples with low smectite content present clay mineral content values very similar to those of Units I and II, whereas some other samples, randomly distributed along the Unit III, show smectite contents three or four times higher than the former, reaching in some cases values near $100 \%$. A similar scenario was described by Do Campo et al (2010) for the beginning of the volcanic activity in the Paleogene Andean foreland of northwestern Argentina. SEM textural images, mineral composition and smectite chemical data demonstrated that the samples had anomalously high smectite contents and represented episodes of volcanic input to the basin. The remainder of the samples showed a low smectite content of detrital origin. In a similar way, we interpret that in the samples showing low smectite content of all the units of the AND-2A drill core, the detrital origin of smectite is the predominant mechanism and the peaks showing major smectite content in Unit III reflect some influence of volcanic activity.

Another important clue supporting the hypothesis of volcanic influence is the Mg- and Ferich composition of authigenic smectite. Chamley (1989) has reported that $\mathrm{Mg}$ and Fe-Mg smectite are the main clay minerals derived from submarine alteration of volcanic rocks. As already mentioned, volcanic material is persistent throughout the AND-2A core and is the dominant clast type $(>50 \%)$ in nine of the 14 lithostratigraphic units (Panter et al., 2008-2009). AND-2A fresh glass is mafic, strongly Si-undersaturated and very similar to mafic-intermediate EVP (Erebus Volcanic Province) whole-rock data (Nyland et al., 2011). Most of the lava clasts from LSU 1 are mafic and Si-undersaturated; whole-rock compositions vary from basanite (AND-2A 10.22) to tephrite and hawaiite.

Franke \& Ehrmann (2010) have compared the smectite concentrations with the number of volcanic clasts in the sediments from the same drill core studied here. In some intervals, smectite peaks correlate with large numbers of volcanic clasts and they may be interpreted as resulting from productive volcanic activity and/or a major influx of volcanic erosional products from the south. In contrast, in other intervals smectite peaks correlate with small numbers of volcanic clasts. In these intervals, the high smectite contents are evidently not caused by volcanic activity and/or erosion of volcanic material. The occurrence of authigenic smectites and other minerals (calcite and framboidal pyrite) in these intervals indicates that the high smectite contents were probably caused by diagenetic processes.

Previous investigations of submarine diagenesis in volcaniclastic successions from Ocean Drilling Program Leg 126, similar to that investigated by the ANDRILL Southern McMurdo Sound project, demonstrate that the principle alteration processes are the formation of hydrous secondary minerals such as phyllosilicates and zeolites, with calcite precipitation and the hydration of volcanic glass (Marsaglia \& Tazaki, 1992; Gifkins et al., 2005).

The change with depth of the alteration products (Figure 6) is characteristic of a diffuse hydrothermal ore complex, indicating proximity to active volcanic complexes. This explanation is also corroborated by a high geothermal gradient inferred from the high down-hole temperatures. Wonik et al. (2008-2009) reported an exceptionally high temperature for the AND-2A drill core. The temperature gradient shows two trends: from 0 to $\sim 1000 \mathrm{mbsf}$ it is $\sim 44^{\circ} \mathrm{C} \mathrm{km}^{-1}$, while in the lower portion of the core it increases to $65^{\circ} \mathrm{C} \mathrm{km}^{-1}$. For comparison, the temperature gradient in CRP-3 was of the order of $25^{\circ} \mathrm{C} \mathrm{km}^{-1}$.

Smectites in AND-2A drill core show very high composition variability, with many analyses well in the compositional gap between di- and tri-octahedral smectites, which supports the fact that authigenic and detrital phases are both present and intimately mixed. 
Some of the smectite analyses show high interlayer charge and/or low Si content, chemical characteristics which could represent illite/smectite interstratified minerals as well as illites. Even if a detailed transmission electron microscopy (TEM) survey confirmed or ruled out such interstratification, their presence in the McMurdo sediments would not be unusual. Metamorphic rocks are exposed in the Transantarctic Mountains, including low-grade metasedimentary rocks of the Skelton Group in the area near the Skelton Glacier (Cook \& Craw, 2002). Such rocks could have supplied illite/ smectite interstratified minerals to the sedimentary basin, typical components of very low-grade metamorphic rocks. Also, some of the authigenic smectites linked to hydrothermal processes (see below) could have reached a slightly higher temperature, developing an incipient illite mixed-layering. Furthermore, we have to take into account the possibility of analytical contamination by $\mathrm{Ca}, \mathrm{Na}$ and $\mathrm{K}$ from other mineralogical phases. In the whole AND-2A drill core, in fact, both calcite and feldspars are widespread from the top to the bottom of the succession (Figures $7 \mathrm{a} \& 7 \mathrm{~b}$ ).

Although authigenic smectite occurs throughout the core, smectites from sediments in Units I and II are predominantly detrital and they formed through weathering of volcanogenic source rocks. Detrital smectites are essentially dioctahedral Fe-Al members of the beidellite-montmorillonite-nontronite series.

Newly formed smectites in the central and the lower part (Unit III) of the sequence are richer in $\mathrm{Mg}$ and $\mathrm{Fe}$ and poorer in $\mathrm{Al}$, and their compositional fields are closer to the saponite and nontronite field. The presence of authigenic smectites in the central and lower part of the sequence is presumably due to early diagenetic processes and/or to alteration of volcanic rock fragments and glass shards, or precipitation from solutions. Furthermore, in a similar way to the processes described by Cuadros et al. (2011) in the triple junction of the Pacific, Antarctic and Nazca plates and by Manuella et al. (2012) in the Hyblean Plateau, hydrothermalism should have played an important role in the formation of authigenic smectites in the McMurdo Sound.

This study attest to the importance of clearly determining the nature of clay mineral assemblages from marine sediments since they can represent an important proxy of paleoclimatic and paleoenvironmental conditions only when they are of detrital origin.
Therefore our research confirms that FESEMSEM textural and morphological observations of fine-grained sediments are fundamental to identifying whether clay minerals can be interpreted as a proxy of paleoclimatic conditions.

Acknowledgments - We are grateful to Javier Cuadros and an anonymous reviewer for constructive reviews. This research has been funded by the ANDRILL Program (a multinational collaboration between the Antarctic programs of Germany, Italy, New Zealand and the United States). Financial support has been supplied by the Italian Programma Nazionale di Ricerche in Antartide (PNRA), PRIN 2008 (F. M. Talarico) grants, the Research Project CGL2011-30153-C02-01 (Spanish Ministry of Science and Technology) and Research Group RNM-179 of the Junta de Andalucía

\section{References}

Abad I., Jimenez-Millan J., Molina J.M., Nieto F., and Vera J.A. (2003) Anomalous reverse zoning of saponite and corrensite caused by contact metamorphism and hydrothermal alteration of marly rocks associated with subvolcanic bodies. Clays and Clay Minerals, 51, 543-554.

Acton G., Crampton J., Di Vincenzo G., Fielding C.G., Florindo F., Hannah M.J., Harwood D.M., Ishman S.E., Johnson K., Jovane L., Levy R.H., Lum B., Marcano M.C., Mukasa S.B., Ohneiser C., Olney M., Riesselman C., Sagnotti L., Stefano C., Strada E., Taviani M., Tuzzi E., Verosub K.L., Wilson G.S., Zattin M., and ANDRILL-SMS Science Team. (2008-2009) Preliminary integrated chronostratigraphy of the AND2A core, ANDRILL Southern McMurdo Sound Project, Antarctica. Terra Antartica, 15, 211-220.

ANDRILL SMS Science Team (2010) An integrated age model for the ANDRILL-2A drill core. In: ANDRILL Southern McMurdo Sound Project Science Integration Workshop - Program and Abstracts (K. Kontar, D.M. Harwood, F. Florindo, and S. Fischbein, editors). ANDRILL Contribution \# 16, ANDRILL Science Management Office, University of Nebraska, Lincoln, NE, 113 pp.

Bentley C.R. (1998) Rapid sea-level rise from a West Antarctic ice-sheet collapse: A short-term perspective. Journal of Glaciology. 44, 157-163.

Berner R.A. (1970) Sedimentary pyrite formation. American Journal of Science, 268, 1-23.

Berner R.A. (1980) Early Diagenesis: A Theoretical Approach. Princeton University Press, 256 pp. 
Biscaye P.E. (1965) Mineralogy and sedimentation of recent deep-sea clay in the Atlantic Ocean and adjacent seas and oceans. Geological Society of America Bulletin, $76,803-832$.

Buatier M.D., Karpoff A.M., and Charpentier D. (2002) Clays and zeolite authigenesis in sediments from the flank of the Juan de Fuca Ridge. Clay Minerals, 37, 143-155.

Chamley H. (1989) Clay Sedimentology. Springer, 623 pp.

Cole T.G. (1985) Composition, oxygen isotope geochemistry and origin of smectite in the metalliferous sediments of the Bauer Deep, southeast Pacific. Geochimica et Cosmochimica Acta, 49, 221-235.

Cole T.G. and Shaw H.F. (1983) The nature and origin of authigenic smectites in some recent marine sediments. Clay Minerals, 18, 239-252.

Cook Y.A. and Craw D. (2002) Neoproterozoic structural slices in the Ross Orogen, Skelton Glacier area, South Victoria Land, Antarctica. New Zealand Journal of Geology and Geophysics, 45, 133-143.

Cuadros J., Dekov V.M., Arroyo X., and Nieto F. (2011) Smectite formation in submarine hydrothermal sediments: Samples from the HMS Challenger Expedition (1872-1876). Clays and Clay Minerals, 59, 147-164.

Decarreau A. and Bonnin D. (1986) Synthesis and crystallogenesis at low temperature of Fe(III)- smectites by evolution of coprecipitated gels: Experiments in partially reducing conditions. Clay Minerals, 21, 861-877.

de la Fuente S., Cuadros J., Fiore S., and Linares J. (2000) Electron microscopy study of the volcanic tuff alteration to illite-smectite under hydrothermal conditions. Clays and Clay Minerals, 48, 339-350.

Del Carlo P., Panter K.S., Bassett K., Bracciali L., Di Vincenzo G., and Rocchi S. (2009) The upper lithostratigraphic unit of ANDRILL AND-2A core (Southern McMurdo Sound, Antarctica): Local volcanic sources, paleoenvironmental implications and subsidence in the western Victoria Land Basin. Global and Planetary Change, 69, 142-161.

Denton G.H. and Hughes T.J. (2000) Reconstruction of the Ross Ice drainage system, Antarctica, at the Last Glacial Maximum. Geografiska Annaler, Series A, 82, 143-166.

Diekmann B., Petschick R., Gingele F.X., Fütterer D.K., Abelmann A., Brathauer U., Gersonde R., and Mackensen A. (1996) Clay mineral fluctuations in Late Quaternary sediments of the southeastern South Atlantic: Implications for past changes of deep water advection. Pp. 621-644 in: The South Atlantic: Present and Past Circulation (G. Wefer, W.H. Berger, G.
Siedler, and D.J. Webb, editors). Springer, Berlin.

Di Vincenzo G., Bracciali L., Del Carlo P., Panter K., and Rocchi S. (2010) ${ }^{40} \mathrm{Ar}-{ }^{39} \mathrm{Ar}$ dating of volcanogenic products from the AND-2A core (ANDRILL Southern McMurdo Sound Project, Antarctica): Correlations with the Erebus Volcanic Province and implications for the age model of the core. Bulletin of Volcanology, 72, 487-505.

Do Campo M., del Papa C., Nieto F., Hongn F., and Petrinovic I. (2010) Integrated analysis for constraining palaeoclimatic and volcanic influences on claymineral assemblages in orogenic basins (Palaeogene Andean foreland, Northwestern Argentina). Sedimentary Geology, 228, 98-112.

Drief A., Nieto F., and Sánchez-Navas A. (2001) Experimental clay-mineral formation from a subvolcanic rock by interaction with $1 \mathrm{~m} \mathrm{NaOH}$ solution at room temperature. Clays and Clay Minerals, 49, 92-106.

Ehrmann W. (1998) Implications of Late Eocene to Early Miocene clay mineral assemblages in McMurdo Sound (Ross Sea, Antarctica) on paleoclimate and ice dynamics. Paleogeography, Paleoclimatology, Paleoecology, 139, 213-231.

Ehrmann W. (2000) Smectite content and crystallinity in sediments from CRP-2/2A, Victoria Land Basin, Antarctica. Terra Antartica, 7, 575-580.

Ehrmann W. (2001) Variations in smectite content and crystallinity in sediments from CRP-3, Victoria Land Basin, Antarctica. Terra Antartica, 8, 533-542.

Ehrmann W.U and Mackensen A. (1992) Sedimentological evidence for the formation of an East Antarctic ice sheet in Eocene/Oligocene time. Palaeogeography, Palaeoclimatology, Palaeoecology, 93, 85-112.

Ehrmann W., Melles M., Kuhn G., and Grobe H. (1992) Significance of clay mineral assemblages in the Antarctic Ocean. Marine Geology, 107, 249-273.

Ehrmann W., Bloemendal J., Hambrey M.J., McKelvey B., and Whitehead J. (2003) Variations in the composition of the clay fraction of the Cenozoic Pagodroma Group: Implications for determining provenance. Sedimentary Geology, 161, 131-152.

Ehrmann W., Setti M., and Marinoni L. (2005) Clay minerals in Cenozoic sediments off Cape Roberts (McMurdo Sound, Antarctica) reveal palaeoclimatic history. Palaeogeography, Palaeoclimatology, Palaeoecology, 229, 187-211.

Fesharaki O., García Romero E., Cuevas-González N., and López-Martinéz N. (2007) Clay mineral genesis and chemical evolution in the Miocene sediments of Somosaguas, Madrid Basin, Spain. Clay Minerals, 42, 173-187. 
Fielding C.R., Atkins C.B., Basset K.N., Browne G.H., Dunbar G.B., Field B.D., Frank T.D., Krissek L.A., Panter K.S., Passchier S., Pekar S.F., Sandroni S., Talarico F., and ANDRILL-SMS Science Team (20082009) Sedimentology and stratigraphy of the AND2A core, ANDRILL Southern McMurdo Sound Project, Antarctica. Terra Antartica, 15, 77-112.

Fielding C.R., Browne G.H., Field B., Florindo F., Harwood D.M., Krissek L.A., Levy R.H., Panter K.S., Passchier S., and Pekar S. F (2011) Sequence stratigraphy of the ANDRILL AND-2A drillcore, Antarctica: A long-term, ice-proximal record of Early to MidMiocene climate, sea-level and glacial dynamism. Palaeogeography, Palaeoclimatology, Palaeoecology 305, 337-351.

Fitzgerald P. (2002) Tectonics and landscape evolution of the Antarctic plate since the breakup of Gondwana, with an emphasis on the West Antarctic Rift System and the Transantarctic Mountains. Pp. 453469 in: Antarctica at the close of a millennium: Royal Society of New Zealand Bulletin, 35 (J.A. Gamble, D.N.B. Skinner, and S. Henry, editors).

Franke D. and Ehrmann W. (2010) Neogene clay mineral assemblages in the AND-2A drill core (McMurdo Sound, Antarctica) and their implications for environmental change. Paleogeography, Paleoclimatology, Paleoecology, 286, 55-65.

Gifkins C., Hermann W. and Large R. (2005) Altered Volcanic Rocks: A Guide to Description and Interpretation. Centre for Ore Deposit Research (CODES), University of Tasmania, Australia, 275 pp.

Giorgetti G., Aghib F.S., Livi K.J.T., Gaillot A.C., and Wilson, T.J. (2007) Newly formed phyllosilicates in rock matrices and fractures from CRP-3 core (Antarctica): An electron microscopy study. Clay Minerals, $42,21-43$.

Giorgetti G., Talarico F., Sandroni S., and Zeoli A. (2009) Provenance of Pleistocene sediments in the ANDRILL AND-1B drill core: Clay and heavy mineral data. Global and Planetary Change, 69, 94-102.

Harwood D.M., Florindo F., Talarico F.M., Levy R.H., Kuhn G., Naish T., Niessen F., Powell R., Pyne A., and Wilson G. (2009) Antarctic drilling recovers stratigraphic records from the continental margin. Eos, 90, 90-91.

Hein J.R. and Scholl D.W. (1978) Diagenesis and distribution of late Cenozoic volcanic sediment in the southern Bering Sea. Bulletin of Geological Society of America, 89, 197-210.

Hillier S. (1995) Erosion, sedimentation and sedimentary origin of clays. Pp. 162-219 in: Origin and mineralogy of clays (B. Velde, editor). Springer, Berlin.
Huertas F.J., Cuadros J., Huertas F., and Linares J. (2000) Experimental study of the hydrothermal formation of smectite in the beidellite-saponite series. American Journal of Science, 300, 504-527.

Jimenez-Millan J., Abad I., and Nieto F. (2008) Contrasting Alteration Processes in Hydrothermally Altered Dolerites from the Betic Cordillera, Spain. Clay Minerals, 43, 267-280.

Kastner M. (1981) Authigenic silicates in deep-sea sediments: Formation and diagenesis. Pp. 915-980 in: The Sea, 7 (C. Emiliani, editor). Wiley, New York.

Kretz R. (1983) Symbols for rock-forming minerals. American Mineralogist, 68, 277-279.

Kurnusov V.B., Kholodokevich V., Kokorina L.P., Kotov N.V., and Chudaev O.V. (1982) The origin of clay minerals in the oceanic crust revealed by natural and experimental data. Proceedings of the International Clay Conference, Bologna and Pavia, 547-556.

Kyle P.R. (1990) McMurdo Volcanic Group, western Ross Embayment. Introduction. Pp. 19-25 in: Volcanoes of the Antarctic plate and Southern Oceans: AGU Antarctic Research Series, 48, (W.E. Le Masurier and J.W. Thomson, editors).

Lovley D.R. (1991) Dissimilatory Fe(III) and Mn(IV) reduction. Microbiological Reviews, 55, 259-287.

Manuella F.C., Carbone S., and Barreca G. (2012) Origin of saponite-rich clays in a fossil serpentinite-hosted hydrothermal system in the crustal basement of the Hyblean Plateau (Sicily, Italy). Clays and Clay Minerals, 60, 18-31.

Marsaglia K.M. and Tazaki K. (1992) Diagenetic trends in Leg 126 sandstones. Proceedings of the Ocean Drilling Program, Scientific Results, 126, 125-138.

Moorby S.A. and Cronan D.S. (1983) The geochemistry of hydrothermal and pelagic sediments from the Galapagos hydrothermal mounds field. DSDP Leg 70. Mineralogical Magazine, 47, 291-300.

Nyland R, Panter K., Del Carlo P., Di Vincenzo G., Rocchi S., Tiepolo M., and Field B. (2011) Evidence for early-phase explosive basaltic volcanism at $\mathrm{Mt}$. Morning from glass-rich sediments in the ANDRILL AND-2A core and possible response to glacial cyclicity. Abstract. 11th International Symposium on Antarctic Earth Sciences, 10-15 July 2011, Edinburgh, Scotland.

Panter K.S., Talarico F., Bassett K., Del Carlo P., Field B., Frank T., Hoffman S., Kuhn G., Reichelt L., Sandroni S., Taviani M., Bracciali L., Cornamusini G., von Eynatten H., Rocchi S., and the ANDRILL SMS Science Team. (2008-2009) Petrologic and Geochemical Composition of the AND-2A Core, ANDRILL Southern 
McMurdo Sound Project, Antarctica. Terra Antartica, $15,147-192$.

Passchier S., Browne G., Field B., Fielding C.R., Krissek L.A., Panter K., Pekar S.F., and ANDRILL SMS Science Team (2011) Early and Middle Miocene Antarctic glacial history from the sedimentary facies distribution in the AND-2A drill hole, Ross Sea, Antarctica. Geological Society of America Bulletin, 123, 2352-2365.

Petschick R. (2001) MacDiff 4.2.5. http://www.geolpal. uni-frankfurt.de/Staff/Homepages/Petschick/MacDiff/MacDiffInfoE.html

Petschick R., Kuhn G., and Gingele F. (1996) Clay mineral distribution in surface sediments of the South Atlantic: Sources, transport, and relation to oceanography. Marine Geology, 130, 203-229.

Setti M., Marinoni L., Lòpez-Galindo A., and Ben Aboud A. (1997) XRD, SEM and TEM investigations of smectite of the core CIROS-1 (Ross Sea, Antarctica). Terra Antartica, 4, 119-125.

Setti M. Marinoni L., Lòpez-Galindo A., and Ben Aboud A. (1998) TEM observations and Rare Earth element analysis on the clay minerals of the CRP-1 Core (Ross-Sea, Antarctica). Terra Antartica, 5, 621-626.

Setti M., Marinoni L., Lòpez-Galindo A., and DelgadoHuertas A. (2000) Compositional and morphological features of the smectite of the sediments of the CRP2A Core, Victoria Land Basin, Antarctica. Terra Antartica, 7, 581-587.

Setti M., Marinoni L., and Lòpez-Galindo A. (2001) Crystal-chemistry of smectite in sediments of CRP 3 Drillcore (Victoria Land Basin, Antarctica): Preliminary results. Terra Antartica, 8, 543-550.
Setti M., Marinoni L., and Lòpez-Galindo A. (2004) Mineralogical and geochemical characteristics (major, minor, trace elements and REE) of detrital and authigenic clay minerals in a Cenozoic sequence from Ross Sea, Antarctica. Clay Minerals, 39, 405-421.

Singer A. (1984) The paleoclimatic interpretation of clay minerals in sediments: A review. Earth-Science Reviews, 21, 251-293.

Vitali F., Blanc G., Larqué P., Duplay J., and Morvan G. (1999) Thermal diagenesis of clay minerals within volcanogenic material from the Tonga convergent margin. Marine Geology, 157, 105-125.

Weaver C.E. (1989) Clays, Muds and Shales, Developments in Sedimentology, 44. Elsevier, 819 pp.

Wise S.W., Smellie J., Aghib F.S., Jarrad R., and Krissek L. (2001) Authigenic smectite clay coats in CRP-3 Drillcore, Victoria Land Basin, Antarctica, as possible indicators of fluid flow: A progress report. Terra Antartica, 8, 281-298.

Wonik T., Grelle T., Handwerger D., Jarrard R.D., McKee A., Patterson T., Paulsen T., Pierdominici S., Schmitt D.R., Schröder H., Speece M., Wilson T., and the ANDRILL-SMS Science Team (2008-2009) Downhole Measurements in the AND-2A Core, ANDRILL Southern McMurdo Sound Project, Antarctica. Terra Antartica, 15, 57-68. 